\title{
Sakha Language Terminography Overview
}

\author{
Egor Innokentevich Okoneshnikov ${ }^{1}$, Aleksandra Spartakovna Akimova ${ }^{1, *}$, Yuliya \\ Mikhailovna Borisova $^{1}$, Marina Stepanovna Delannois ${ }^{2}$
}

\author{
${ }^{I}$ Yakut language Department, The Institute for Humanities Research and Indigenous Studies of the North Siberian Branch \\ of the Russian Academy of Sciences, Yakutsk, Russia \\ ${ }^{2}$ Department of Foreign Languages for Humanitarian Specialities, North Eastern Federal University, Yakutsk, Russia \\ * Corresponding author. Email: sikkier84@mail.ru
}

\begin{abstract}
This article observes the formation and the making of the Yakut language terminology, in particular the selection and quality of dictionary glossary and their compositional (inventory and interprative) characteristics. The authors substantiate and analyze a new direction in Yakut linguistics called terminography. Moreover, they give a classification analysis of terminological dictionaries by typologies and compositional characteristics. Compositional characteristics can be diversified, complex, single branch and narrow branch as shown in Sakha terminological dictionaries.
\end{abstract}

Keywords: Yakut language, term, terminography, dictionary, definition, explanation, glossary

\section{INTRODUCTION}

Nowadays a comprehensive study of terminography as a separate scientific discipline is becoming of a paramount importance. It is estimated that on average every 25 years the number of scientific disciplines doubles. Moreover, each new discipline needs its own terminology. In our country, there has been an intensive increase in the number of terminological dissertation research. It is no coincidence that a new direction appeared called terminography.

The opposition terminography versus lexicography seems to have appeared together with the term terminography which was introduced in 1975 in the ISO 1087 standard to replace the terms terminological lexicography and special lexicography. It seems, however, that terminography was not supposed to be just a short form for terminological lexicography. R. Hartmann and G. James explain in their "Dictionary of Lexicography" that the term terminography was coined on the analogy of lexicology:lexicography: terminology: terminography. The primary aim of this term was to emphasize that lexicography should only deal with the description of the general vocabulary, whereas the description of terminology should be accounted for by another discipline [1].

For a better understanding of the research material, we will define the term termography. Terminography is the theory and practice of compiling dictionaries of specific vocabulary. The subject of its research is the development of typology principles and classification of terminological dictionaries, the development of optimal methods of selecting special vocabulary for certain types of dictionaries and the setting of single methods and techniques of interpretation characteristics (definitioninterpretation, translation, attribution etc.) of terminology units in specific dictionaries. As we can see, the terminography has theoretical and practical directions. Terminologists are involved in theoretical activities while terminology compilers in practical [2].

Scientific knowledge is traditionally grouped into three blocks: a) natural sciences; b) social sciences; c) scientific and technical sciences. The Yakut terminography has dictionaries for all these branches of knowledge. Natural sciences - 9, social (humanitarian) - 6, technical - 1 dictionary in two books. In addition, we have 4 macrocompositional (diversified) dictionaries. Among them is the "Russian-Yakut terminological and spelling dictionary" by P.A. Oyunskiy containing over 13 thousand word terms.

\section{METHODOLOGY}

The overarching goal of general terminographic analysis is the assessment of the state of terminographic practice in a given area (such as, for example a country) or of a particular society (such as a nation) over a particular time. Detailed terminographic analysis investigates dictionaries according to a complete or pre-selected set of parameters at all structural levels (mega-, macro-, medio- and microstructure) as well as content-wise [3].

Specific vocabulary dictionaries are divided into two main types according to the method of attribution: inventory terminography and interpretation terminography. 
Terms inventory is a collection and description of all term words belonging to a selected field of knowledge or its thematic fragment. Such streamlining is a priority and corresponds to the first stage of terminological research, where the necessary minimum of terms on a selected topic is described. This type of the Yakut language dictionaries include: 1) "Russian-Yakut term-spelling dictionary" compiled by Oyunskiy P.A., Moscow, 1935; 2) "Brief Dictionary of Learning Terms" by a collective author Yakutsk, 1942; 3) "Brief terminological dictionary" compiled by Barashkov P.P., Yakutsk, 1956; 4) "RussianYakut systematized dictionary" compiled by Danilov V.N., Yakutsk, 1980; 5) "Brief Russian-Yakut Dictionary of Biological Terms" compiled by Makarov A.A., Yakutsk, 1974; 6) "Russian-Yakut Dictionary of Biological Terms", edited by Ugarova G.S., Yakutsk, 1993; 7) "Brief Russian-Yakut Dictionary of Economic Terms" compiled by Byganova V.I., Yakutsk, 1998; 8) "Russian-Sakha Social Political Dictionary" compiled by Okoneshnikov E.I., Yakutsk, 1998; 9) "Russian-Yakut Law Dictionary" collective author Yakutsk, 2000; 10) "Dictionary of Russian-Latin-Yakut names of plants of Yakutia" compiled by Petrov A.M., Yakutsk, 2002.

The inventory dictionaries in grain are Russian-Yakut that once again is confirmed by the leading role of the Russian terminological school. New concepts with their designations come to us through the Russian language.

The interpretation type includes dictionaries, where the title vocables are provided with definitions (brief interpretations). The definition should be accurate, concise but sufficient without any extra information. As a result, the meaning of one of the ambiguous word becomes terminological. The definition consists of one sentence with nothing extra. The terminological meaning of the ambiguous word kyūs is given with the following definition: 'measure of a mechanical action on a given material body by another body' in the physical dictionary by Samsonov G.G., Suzdalov I.I., Yakovlev P.A. "Explanatory dictionary of physical term", Yakutsk, 1997. $88 \mathrm{pp}$. Definition is a very good technique for highlighting the terminological meaning of an ambiguous word and a word with an undifferentiated meaning. In the early stages of streamlining terminology, incomplete and excessive definitions are acceptable.

\section{RESULTS}

The Yakut terminography has the following interpretation dictionaries: 1) "Russian-Yakut poetry dictionary", compiled by Vasiliev G.M.,Yakutsk, 1976; 2) "Dictionary of linguistic terminology of the Yakut language", compiled by Cherosov M.A. Yakutsk, 1977; 3) "Dictionary of geographical terms", compiled by Maksimov G.I., Sivtseva A.I. Yakutsk, 1993; 4) "Brief Russian-Yakut Dictionary of Scientific and Technical Terms", edited by Gurieva K.N., Yakutsk, 1994 in two parts; 5) "Dictionary of Physical Terms", collective author
Yakutsk, 1997; 6) "Russian-Yakut Dictionary of Mathematical Terms", collective author Yakutsk, 1998; 7) "Dictionary of astronomical terms", compiled by Yakovlev B.A., Yakutsk, 1998; 8) "Explanatory Dictionary of Chemical Terms", compiled by Egorov N.V., Koryakina A.G., Yakutsk, 2000; 9) "Explanatory Environmental Dictionary", compiled by Ivanov V.S., Yakutsk, 2001; 10) "Conceptual and terminological Russian-Yakut dictionary of psychology", scientific advisor Okoneshnikova A.P., Yakutsk, 2006.

Theoretical and applied questions of terminology were studied by P.A. Oyunskiy, A.A. Ivanova-Kynde, G.V. Baisheva-Altan Saryna and also partially studied by A.E. Kulakovskiy, S.A. Novgorodova, L.N. Kharitonova, E.I. Ubryatova, N.K. Antonova N.D. Dyachkovskiy, P.A. Sleptsova, P.S. Afanasyeva, N.V. Skrybykina and others. The candidate dissertation of V.I. Byganova is devoted to the stages of formation and development of the Yakut terminology, doctoral dissertation of E.I. Okoneshnikova to the linguistic aspects of Sakha terminology. The Yakut terminology was successfully studied by L.A. AfanasyevTeris, M.P. Alekseev-Dapses. Currently, Okoneshnikov E.I., Akimova A.S., Borisova Yu.M. are working on the terminology of the Yakut language.

Central to lexicographic (terminographic) theory is the doctrine of the types of dictionaries, the composition of the glossary, and the structure of dictionary entries. Since terminological dictionaries intersect for some reasons, the faceted division principle was subsequently adopted. The faceted typology is convenient for dividing the varieties of dictionaries according to their parallel bases. It, like any other typology, involves the allocation of the main lexicographic parameters for the classification of dictionaries. In Russian terminography, there are dozens of such parameters as some terminologists indicate [4].

The faceted typology (classification) is used with greater efficiency in the description of diversified, multi-aspect terminological dictionaries. The Yakut terminography consisting of diversified and mixed dictionaries needs a faceted typology. The faceted typology like any other involves the allocation of certain lexicographic characteristics that serve as the basis for the dictionaries classification. Obviously, the classification of dictionaries, firstly, must be based on their most important distinguishing features. It is noted that the distinctive feature of the Yakut terminological dictionaries is their compositional structure. Compositional characteristics consist of the following differential features: a) dictionary coverage (diversified, branch-wise, narrow branch); b) the composition of the title vocables; c) the content of the dictionary entry (translation, definition, encyclopedic reference); d) the method of ordering (alphabetic, alphabetic-index); e) aim and purpose (inventory, interpretative); f) language coverage (bilingual, monolingual, multilingual). 


\section{DISCUSSIONS}

The composition of the terminological dictionary is considered to be the content choice, the position of the right and left parts of the dictionary, content and design of dictionary entries. Researchers distinguish a macrotext which considers the dictionary as a single whole, and a microtext which considers it into as a separate dictionary entry. Compositional parameters, as shown by Sakha terminological dictionaries, can be diversified, complex, single-branch and narrow-branch.

The Yakut diversified terminological dictionaries are divided into dictionaries without references indicating areas of knowledge, and dictionaries with a heading layout into branches of knowledge. The third group consists of diversified dictionaries, where dictionary entries are provided with special references.

The first group includes the "Russian-Yakut terminological and spelling dictionary" by P. A. Oyunskiy, "Russian-Yakut terminological dictionary" by Ivanov A.A.- KYnde , "Dictionary of Ecology" by .S. Ivanova. The right and the left parts of the dictionaries by P.A. Oyunskiy and A.A. Ivanova-Kyndé do not have large terminological differences.

Regarding the dictionary of P.A. Oyunsky, at first it was supposed to publish a series of dictionaries in all subjects of a comprehensive secondary school and a small social political dictionary. However, in the process, they were all compiled into one. About the purpose of the dictionary, the author wrote: "... The dictionary is designed to be used in compiling textbooks and teaching guides within elementary and secondary schools" [5]. In terms of the word terms and terminological phrases scope related to various branches of knowledge, the dictionary goes far beyond the requirements of school curricula and is more vast with terminological vocabulary than all the previous and subsequent dictionaries. The dictionary contains 13008 title units and by its lexicographic feature belongs to the bilingual translation dictionaries of terminological vocabulary [6].

Below we briefly look at the part of the glossary dictionary that in modern terminography is considered to be excessive.

1) In addition to common nouns, proper names and geographical names are entered in the dictionary. Among them are the names of ancient philosophers, politicians, scientists, writers, princes up to literary characters. The names of districts, regions, cities, territories, republics, states, lakes, seas, rivers, islands, volcanoes, mountains etc. are included in geographical names.

2) The glossary has various phrases, with rare exceptions which are difficult to attribute to terminological phrases in the modern sense. We give several examples such as reflected in the report, outlawed, offered to take a horse, three multiply by three, a formalized decision etc.

3) There are a lot of Russisms that did not subsequently enrich the terminological vocabulary of the Sakha language, although they were spelled according to the phonetics of the input language, such as izbach 'isbēs', speech 'ispīs', unikum 'ūnn'ukum', monolith 'manalȳt' etc.

However, it is important to note that P.A. Oyunskiy made a huge contribution to the further development of Yakut terminography. As Borisova Yu.M. writes, "P. A. Oyunskiy introduced the following in the formation of terms: 1 . The gender form of nouns in certain conditions is lexicized and acquires a terminological function: circumference 'tyogyuryumtete', vegetation 'yūnēyite', determination 'sorunūlāgha'. 2. Modernism terms that have arisen as a result of lexical semantic shifts of their meanings are often found in the "Dictionary", for example, fuel 'ubatyk', volume 'sabardam', split 'haidyhȳ', body 'ettik'. 3. The multivariate methods of term formation recorded in the Dictionary, can be divided into two groups: a) original synonymous terms like palm 'ytys, bappaghai', power 'kuȳs, kyah'; b) along with the Russian borrowing there is a Yakut equivalent like, method 'mietet, n'yma', secretary 'sekeritēr, suruksut'. 4. There is an example of an affixational term formation like, superpower 'tutūnnyu', art 'uramn'y', image 'dyuhyumer', level 'tahym' etc. 5. There is a big amount of terminological phrases consisting of complex and composite elements like, animal husbandry 'syuyohyu ìtīte', gold 'kyhyl kyomyus', pupil 'harah ichite', crossbill 'ymȳ chȳchāgha', harrier 'hār ebe' etc." [7].

KYnde's dictionary abounds with such excess material. First of all, the so-called "non-terminological" parts of speech are given as title units in mass order. Among them, various kinds of verbs: dominate 'bastȳr, toyorgūr', shine 'kylbachyi', mock 'elektē', kyulyū gyn', undergo 'tigis, tyubes' etc. Along with the verbs, adverbs like obscenely 'syol', indifferently 'senērbekke, āhaybakka', accidentally 'tyubespichche, denne' and others are also given. Many vocabulary units are fixed as plurals such as atoms 'ātamnar', points 'bāllar', debts 'ies', liquidators ehechchiler' etc. To the above, one could add the presence of excessive Greco-Latin borrowings of scientific terms, especially in chemistry and medicine.

The presence of the so-called excess material in the Oyunskiy and Kynde dictionaries is dictated by their conscious orientation to expanding the layer of terminological vocabulary at the beginning of its origin. They as theorists and practicians of the language, understood well that terminology is a sphere of intellectually organized activity of people. The terminology creation largely depends on the artificial intervention of different fields' specialists, primarily on people who are well versed in the immense wealth of native language. They as major experts in their native language have introduced many lexicographic and terminographic innovations into their activities. In particular, they showed in practice the examples of creating word terms by means of lexical semantic rethinking of commonly used words, by means of 
affixational word formation and by methods of two and numerous word combinations.

The second group consists of diversified (mixed) dictionaries with a layout into branches of knowledge. Even in the pre-war period, a short "Russian-Yakut Dictionary of Educational Terms" for secondary schools was compiled and published in 1942 under the guidance of the Yakutsk Institute of Language and Culture.

The work on the dictionary coincided in time with a turning point of the translation of written languages of national republics into Cyrillic. The dictionary has five sections on Geography, Natural sciences, Mathematics, Physics and Chemistry. The compilers were well-known experts in their fields of knowledge: G.I. Sleptsov (Geography), P.P. Larionov and S.O. Onoprov (Natural sciences), A.S. Sofronov (Mathematics), M.A. Alekseev (Physics), A.D. Egorov (Chemistry). It is a Russian-Yakut translation dictionary with 1135 word terms and terminological phrases in these five areas of knowledge. According to estimatations by the Professor P.A. Sleptsova, there are $40.9 \%$ - Russian borrowings, 9.3\% hybrid terms, $7.2 \%$ - tracing papers, $42.6 \%$ - original terms [8]. The dictionary was published in 5000 copies and was used as the only educational textbook until the 90 s of the last century.

As an example of a diversified terminological dictionary with a layout into branches of knowledge, we present the "Brief Russian-Yakut Dictionary of Scientific and Technical Terms" in two books. The publication of this dictionary marked a turning point in the inventory and interpretation of the Yakut scientific and technical terminological vocabulary. For the first time in Yakut terminography, 3084 scientific and technical word terms and terminological phrases were selected and provided with interpretation translations. "Scientific and technical terms" is a broad concept that has not been sufficiently studied. In addition, the compilers preferred an expansive interpretation of the scientific and technical terminological vocabulary of the Sakha language. As a result, the dictionary contains the following sections in various fields: architecture and construction, geology, mining, invention and rationalization, engineering graphics, astronautics, mechanical engineering, land reclamation, mineral processing, welding, agriculture, transport, chemistry, energy and communications. To the credit of the compilers, we emphasize that mainly suitable Yakut equivalents were selected for the Russian title units that in a more favourable language situation could well be used in the meaning of term words and terminological phrases. According to our estimations, Russian borrowings throughout the dictionary body comprise $13.7 \%$ of the total number of word terms entered in the dictionary, the rest are original and hybrid formations.

A diversified dictionary with notes indicating a field of knowledge. This group of diversified dictionaries includes the "Short Terminological Dictionary of the Yakut Language" (Yakutsk, 1965). The dictionary contains over 4,000 word terms and terminological phrases, covering, according to the author's own notes, the following sections of knowledge: aviation, the everyday term, veterinary medicine, geography, natural sciences, and many others. In total, the dictionary has 51 sections devoted to different fields of knowledge. The publication most clearly and graphically reflected the increasing influence of the Russian language on the formation and development of Yakut terminological vocabulary. Here are the results of the analysis of dictionary units with the letter "A". A total of 197 vocabulary units have been entered where we find 9 original terms such as stork 'ehir', prisoner 'hāiyylāh' affix 'syhyarȳ'; 8 word terms in a phonetized version like diamond 'almās', arch 'ārk', artel 'artyal'; 11 units in a synonymous version such as avant-garde 'inniki eterēt, avangard', American 'amerikanetc, america kihite', applause 'aplodisment, ytys tahynȳ'; 4 units in a hybrid form such as ammonia water 'ammiaktah uu', atomic weight 'atomnai yiāhyn'. Thus, there are only 9 original, 23 mixed terms, and the rest are Russian (foreign) borrowings. In dictionaries compiled in the 50s, according to Professor P.A. Sleptsova, "an everincreasing influence of the Russian language reflected to a certain extent on the development of terminology: the terms of the latest period have been exclusively borrowed from the Russian language, and some of the original terms have been also replaced by Russian" [9].

Comprehensive dictionary in two parts. Take a look at the "Russian-Yakut Dictionary of Biological Terms" created by a team of authors edited by the Doctor of Biological Sciences, Professor G.S. Ugarova. The Anatomy, Physiology and Human hygiene, Botany, Zoology, Taxa, Animals and plants of Yakutia, Birds, Fish, and invertebrates have been combined into separate chapters under the common name "Biology". Then the "Species of mammals and birds listed in the Red Book of Yakutia" have been added as a separate block. Moreover, unlike other dictionaries, this dictionary contains the Russian-Yakut-Latin names of animals and plants listed in the Red Book of Yakutia. It turns out that the dictionary consists of two parts. The second part consists of two subheadings. The first one is Animals, Birds, Fish, Invertebrates etc. The next one has the subtitle "Species of mammals and birds listed in the Red Book of Yakutia" where we find Animals and birds, Plants, Shrubs, Herbs, Sedge, Beans; Medicinal plants, Berry plants, Cultivated plants, Mushrooms etc. Highly qualified specialists, nature experts participated in the compilation of the dictionary. The presence of Russian-Yakut-Latin names of animals, birds, fish, plants, etc., listed in the Red Book of Yakutia, makes the dictionary a truly unique directory of the animal and plant world of Yakutia.

Comprehensive dictionaries with a layout by subtopics. The "Conceptual and terminological Russian-Yakut dictionary of Psychology" (Yakutsk, 2006) contains the following thematic groups: General Psychology, Physiological foundations, Developmental Psychology, Educational Psychology, Sports Psychology, Psychocorrection, Psychotherapy, Medical Psychology, 
Defectology, Mathematical Psychology, Labour Psychology, Career-oriented Psychology, Personality Psychology, Social Psychology, Educational Psychology. The dictionary covers, as you can see, many sections, including those that are not directly related to the topic. It is a complex dictionary with a layout into subtopics. We note that all the title psychological, including very specific terms are in the Sakha language. At the same time, extensive encyclopedic explanations are given as translations through the dash.

For the first time in Yakut terminography, a long-term posthumous trilingual work of the famous geobotanist

A.M. Petrov "Dictionary of Russian-Latin-Yakut names of plants of Yakutia" was published in 2002. The dictionary includes 1560 biological and botanical unit terms, given in three rows in a vertical arrangement. First, the Russian term is given horizontally, the Latin name in the middle and the Yakut translation is at the end. Its main term types are registered under the generic names. In this regard, the author strictly adheres to the alphabetical index arrangement of dictionary entries. The gender term is given in bold, the main in plain. The "Alphabetical names of families and genera of plants" are given in Russian and Yakut languages in the Appendix. The dictionary includes Russian, Latin, Yakut names of 87 families, 444 genera and 1560 species of plants in Yakutia.

Historically single branch dictionaries appear soon after the diversified and in fact are the basis for the creation and deployment of the terminological branch of linguistics. Such dictionaries by their structure are classified into two types: alphabetically translated and alphabetical translational interpretative. The goal of the first type is the selection and translation of word terms belonging to a specific subject area of knowledge or its thematic fragment. As mentioned above, such ordering is a priority and corresponds to the first stage of terminological work. At this stage, the word terms can have an acceptable and working status in addition to successful (real, acceptable) and recommended. The second block of single branch dictionaries are those that have compositional features.

Translation and inventory dictionaries. As an illustration, we cite the "Brief Russian-Yakut Dictionary of Economic Terms", compiled and published by a qualified terminologist the Doctor of Philology Byganova in 1998. The dictionary starts with a "Preface" where the need to create this dictionary is substantiated with the following words: "There was an urgent need for knowledge of terms and concepts that are widely used in business practice due to the functioning of market tools in economics, the development of business and entrepreneurial activity and also the development of foreign economic affairs". It is further indicated that the dictionary included "the most important and frequently used terms in economics" [10]. Based on these author's arrangements, it is an inventory type of dictionary with a limited scope. The selection of the glossary is based on the principle of widespread use and importance (referring to terms denoting the nuclear concepts of economic science). Such term may not be widely used but very necessary and useful. Unfortunately, the dictionary is small in volume and contains about two thousand economic word terms and terminological phrases. The main units are arranged in a continuous traditional alphabetical order. The way of representing verbose units (terminological phrases) usually causes additional difficulties. The first problem is the question of whether to bring the term phrases into separate articles or to give them within the dictionary article of the main (dominant) word term. The author considers the term phrases as independent dictionary entries and gives them in the alphabetical order of the first word.

The general microcomposition of the dictionary entries is as follows: on the left side is an international or Russian word term or terminological phrase, and on the right side is a translation-equivalent or calque with various marks in brackets or without them. Here are the most typical examples: the equivalent translation like barter 'meneydehī', merchant 'ergiemsik'; a synonymous translation (of four modifications) such as loss 'nochōt, horomnyu', deficit 'depisīt, tutaiȳ', discount 'discount, tuherii'; phonetic translation according to the laws of the input language such as balance 'balansa', broker 'buruokar', bill of exchange 'bieksel'. It was this part that it was possible to make a claim about to the author that she could successfully continue a similar method of translation such as accident 'abaariya', blockade 'bylakāda', subsidy 'datāssiya', crisis 'kirīsis' etc.

The author as a terminographer, at the same time (instead of given ones 'accident', 'blockade', 'subsidy', 'crisis'), successfully used various marks like auction 'auction (kyureh atȳ)', face value '(tabār) yiyllybyt syanata', overhead expenses 'ebī (hos) oroscuot' etc.

In some cases, an explanation like embargo 'embargo (tabāry tiyen killerīni ebeter tahāryyny bobū)', emission 'emission (harchyny, syanalaah kumaagyny ergiirge tahaaryy)' is given along with the equivalent. The output term with the ending in -ost is translated by a word of a similar content but with a Yakut affix of affiliation such as payment 'tyolyobyurdēghe', usefulness 'tuhata', profitability 'barystāgha' etc.

Broad scope translation and inventory dictionary. The "Russian-Yakut Law Dictionary" compiled by the court employees and the prosecutor's office of the republic belongs to the inventory translation type. The dictionary is for a wide range of readers, it contains about 9 thousand word terms of state, civil, criminal, criminal procedure, civil procedure, labor, housing, family, international law, forensic science and criminology. About the goals and objectives of the dictionary it is said that "to give a wide range of readers an intelligible, easy-to-use reference book containing the basic, most common concepts and terms of modern law in Russian and in the Yakut language" [11]. At the same time, the strict principle of selecting the most system-forming legal word terms and terminological phrases is not found in the dictionary. The legal status of such common words as the hanger 'kyohyo', hair 'battah', 
gate 'olbuor āna', stench 'kuhaghan syt', old woman 'emēhsin' etc. is doubtful. The inclusion of well-known words like 'patronage', 'piston' dictionary', 'bullet', 'pistol', 'gun sleeve' etc. are unlikely to be dictated by legal expediency. The feminine gender form seems unnecessary which the authors persistently suggest as a term along with the masculine gender form such as bezdelnik-bezdeltitca (lazybones male-female), grubiyangrubiyanka (rude person male-female), donoschikdonoschitca (informant male-female) etc. There are not many term phrases in the dictionary but they will also apparently require an ordering. Quite a lot of admonition is caused by the right (translated) part of the dictionary. First of all, the verbosity and the presence of long synonymous and quasi-synonymous series such as immigrant 'kyohyoryullyubyut, kyospyut, kyohyon kelbit kihi' (instead of 'kyos kihi'), crime 'prestupnaya, holuobunai buruyu ongorūnan buolara, sierge bappata' (instead of 'buruyu ongorū') is evident. In general, there is a clear authors' subjectivity in the selection of the dictionary glossary and the methods of its terminographic processing,

As the terminological practice of the Yakut language shows, translation interpretational or translation encyclopedic dictionaries are divided into two types: Russian-Yakut and Yakut-Russian. Each Russian-Yakut translation encyclopedic dictionary has its own small compositional difference.

Consider as an example the "Russian-Yakut Dictionary of Mathematical Terms" containing 3,000 basic terms and terminological phrases. It is a Russian-Yakut dictionary and unlike other similar dictionaries, it has a "Preface" and "Introduction" written in Yakut language. In the "Preface" it is noted that translators of mathematics textbooks have been improving the quality of translations every year. As a result, many terms successfully passed the stage of novelty and began to be used permanently. The authors in the Introduction particularly support the point that students easily learn mathematics in their own language. In order to achieve this, the original terminological vocabulary for this branch should be created. Macro and microcompositional characteristics of the dictionary fully meet the goals of streamlining the mathematical terminological vocabulary of the Yakut language. The glossary leaves a quite good impression, except for the presence of long title units, consisting of many components such as the lowest average number divided by two or several rational functions is ikki ebeter has da elbeh-chilien (elbehtem) mungutūr kyra uopsai tyogyulge; The main features of points plotted on an axis and on $X-Y$ plane is the tuochukalar kyonyoghyo uonna haptalga sytȳlaryn syuryun svoistvalara. Perhaps this is the only way to translate the concepts names of complex mathematical units. It leaves us to confide in mathematical experts that they were right. Evidently, there is a large number of Greek-Latin names in Maths. GreekLatin borrowings are listed without changes but with the obligatory indication of their etymone. For example, axiom- axioma (hannyk eme teoria dakāstabyla suoh ylynyllar syuryun balahyann'ata) Greek. axioma ylynyllybyt balahyann'a; operation - operaciya Latin aperato - d'aiyy. The microcomposition of the dictionary entry consists of the following: the title term, the hyphen gives its equivalent (translation or calque), and in parentheses is the definition like kinked curve tohuttaghas (tuochukalartan uonna ol tuochukalary holbūr kerchikteren turar figura); Direction - haiysha (nūl buolbatah vektory ūruktaah chyhylagha tyogyulleen ylyllar vektordar barylara). The lexical semantic innovations created by the authors themselves should be included along. Among them are the word terms such as the fraction 'bytaryk'; denominator 'kyordyoryuk'; range 'tyumseen'; inequation 'tengnehimik'; product 'yuyoscem' and others. It is noteworthy that the authors along with the existing terms, offer their options in parentheses like polygon 'elbeh munnuk (elbienn'ik)'; polynomial 'elbeh-chilien (elbehtem)'; triangle 'yus munnuk (yuhyuyonnyuк)' etc. Compound terms consisting of two components were also innovated by the author, such as the reciprocal of number 'tyungneri chȳhyla' instead of 'tyottyoryu chȳhyla'; inverse fraction 'tyungneri bytaryk' instead of. 'tyottyoryu drob'; common denominator 'uopsai kyordyoryuk' instead of 'uopsay znamenatel' etc. Some encyclopedic explanations like limit 'tyumyulyuk (utum ebeter funciya suoltalara mungura suoh chugahȳr chȳhylalara; mathematichaskai analiz biir syuryun yoidyobyule)' sometime along with the definition are also given. Here, the last sentence is an encyclopedic addition to the definition. In the dictionary body there are translations of title units with the help of synonymous analogs such as vibration 'eyenngnēhin, bietengnēhin, halbangnāhyn, tyullengnenēhin'. As for the dictionary, it contains a strictly alphabetical arrangement of dictionary entries. Terms that are varieties of the generic concept are also given in separate dictionary entries in the alphabet place.

The "Russian-Yakut Dictionary of Chemical Terms" has an alphabetical translational encyclopedic layout. Dictionary entries are in alphabetical-index variant. Title units are given in bold, and index units are in boldface after the symbol $\Delta$ like Substance '(sebd'i, veschestvo) physicheskei ettic tuohtan turara (sastābynan) sebdy dener'. Next, we provide examples of index units in the form they have been registered in the dictionary: $\Delta \mathbf{B}$. nitrogen-containing (azottah $\mathrm{C}$.); $\Delta$ B. active (d'yorghoot C.) $\Delta$ B. inertness (nes C.); $\Delta$ B. initial (tyopyut C.); $\Delta$ B. volatile (kyotyumtyuyo C.); $\Delta$ B. insoluble (sūrallybat SC.) etc., a total of 29 index units. The dictionary entry looks like this: first the title word, its Yakut equivalent (if there is one), definition and encyclopedic interpretation. International terms with a Greek-Latin basis authors preferred to leave without a change (i.e. without translation) such as oil 'harangatyny yongnyouyoh soghus ubaghas sebd'i. Sir annynāghy battāhynga myolyuyonyunen syl ustatygar haramai uonna yuūnēi sytyiȳtyttan yuoskēbit'. The terms that could be 
successfully transcribed, for example, the term oil n'yep, analysis - anālys; atom - ātam; molecule myolyuokyule and others have been included as invariables. Many dictionary entries along with the definition are accompanied by excessively long encyclopedic explanations. The generic term Law (Sokuon) is given with its variety Z. avagadro '(Avagadro S.) - hannyk bagharar gaz teng sabardamygar bīr teng temperaturagha uonna battāhynga teng ahsānnāh molekula bār'. Then follows an encyclopedic explanation that takes up more than one page of the book. Apparently, the Russian dictionaries, reference books and encyclopedias in chemistry used by the authors as dictionary sources are the reason of it. At the same time, there are dictionary entries, accompanied by the selection of successful equivalents, such as fermentation 'kyōnnyū', fiber 'utah, sap', smelting 'uhārȳ', block 'somogho', fuel 'ottuk' etc. It is also noteworthy that the compilers undertook the rehabilitation of words that came out for various reasons from the active use of term words, such as protein 'yuryunges', substance 'sebd'i', lime 'oppuoha', acid 'ahȳba' etc. It should be noted that the Russian terms with the ending on the -ost' are sequentially translated with the Yakut form of affiliation such as humidity 'sīge', rigidity 'kytānagha', density 'chinhe' etc. However, the dictionary glossary is not free from flaws. There are highly specialized term phrases that go beyond school (sometimes university) programs in the index of title units. At the same time there are omissions of the most common chemistry terms such as rubber, amperes, galvanometer, cupronickel, mercuric chloride, foil, tungsten, silicon, nicotine etc. Absorption of the terminological material is also hindered by the lack of dictionary applications. Meanwhile, dictionary entries are literally full of conditional abbreviations.

Monolingual dictionaries with Russian (foreign) inclusions. Teachers of the Yakut State University together with teachers-practitioners released the "Dictionary of Physical Terms" in 1987. In contrast to the dictionaries described, the original word terms or terminological phrases aharāchy (conductor) 'electricheskei tuogu aharar bessestibe'; myolyuokyule (molecule) - 'bessestibe fizicheskei uratylaryn ild'e syldyar syomai kyra elyūske'are given as the title units. If the title term cannot be translated or transcribed, then it is given unchanged, such as mechanics - 'materialnai ettikter hamsāhynnaryn uonna daisȳlaryn tuhunan nauka'; microphone - 'tyas eingnēhinin elektricheskei eingnē kubulutar ongohuk'. Synonym types of terms are sequentially given in the index of the gender term behind the $\Delta$ sign like: $\Delta \bar{a} l s \bar{y}$ '(friction)'. $\Delta$ kurānah $A$ '(dry T) ongunuogha suoh nyūrdāh ikki kytānah ettik ikki ardygar haltaryī̄ ālsȳta'; $\Delta$ mahbırāghy $A$ '(external T)'; $\Delta$ tyokyunyutyū $A$ '(T. rolling) - bīr ettik atyn ettik nyūrunan tyokyunyuieriger yuoskyūr tahynāghy ālsȳ'; $\Delta$ turu $A$. (T peace) - 'hardaryta hamsābat ettikter ālsȳlara'; $\Delta$ ubaghas A. (liquid T.) - 'ubaghas ebeter oghunuoh charās arangatynan byuryullyubyut ettikter ikki ardylarynāghy haltary $\mathrm{A}^{\prime}$. and etc. The micro-composition of the dictionary entries consists of the following: the title term, its Russian equivalent translation is given in brackets, then with the hyphen is the defintion itself (not in the form of interpretations). However, verbose and insufficiently clear definitions are found occasionally. The explanations of symbols, abbreviations etc. are usually given in the 'Appendix' of the dictionaries. This dictionary does not have them, although they (symbols, abbreviations) are spread throughout it. The short "Preface" clarifies the aim and purpose of the dictionary. Since it is the YakutRussian, it has a double meaning, both Russian and Yakut readers can use it. This is the difference between this dictionary and other Russian-Yakut terminological dictionaries. If we discuss the type of the dictionary, then it should consist of original word terms used by the physicists. In general, the authors managed with the original glossary but it was impossible to avoid Russian impregnations like 'astigmatism', 'hysteresis', 'cavitation', 'lepton'. Many title terms could be transcribed according to the phonetic laws of the input language. Examples: 'ātam', 'bataryaia', 'bakānsyia', 'hāmyra', 'maghan'ȳt', 'birīnsip', ‘tyuoryuie', 'elemien' etc.

The teacher of one of the secondary schools of Yakutsk P. Yakovlev published the "Dictionary of Astronomical Terms" in 1998. The title units of the dictionary are arranged in an alphabetical order including the varieties of the generic term. For example, along with the generic term kyun '(sun)' its varieties are also given in the alphabetical form: kyun aktȳbynaha '(solar activity)'; kyun biriemete '(solar time)'; kyn ortoto '(noon)'; kyun radiaciyata '(solar radiation)' etc. In contrast to the "Dictionary of Physical Terms", this dictionary contains additional encyclopedic explanations, often quite broad, such as astrology - 'hallān syrdatāchchylaryn: Kyun, Yi uonna cholbonnor hardaryta nārdanan turūlaryn kytta Sirge buolar d'ingnēh kyostyūleri, d'on-noruot d'ylghatyn sitimnīr yuoreh. Bert bylyr yuoskēbit, orto yuolerge kiengnik targhammyt, kapitalisticheskai doidularga biligin yoryogyoidyōn turar, bihiehe emie kenniki syllarga kyüske targhanan erer. Urut sahalar hallan syrdatāchchylaryn nārdanȳlarynan, altyhȳlarynan kyunyu-d'yly bilgelīllere biller. Kihi etiger-sīniger chugas hallān ettiktere sabydyallāhtaryn tuhunan yuges bihiehe tìyen kelbit'. (An encyclopedic explanation is emphasized in italics). The structure of the dictionary entry is as follows: the dictionary unit is shown in bold, its Russian equivalent in parentheses, then a hyphen followed by a definition, then an encyclopedic explanation. Between the Russian equivalent and the definition, Greek or Latin and other names of planets or stars are wedged in. For example, kuyah '(shield) (from Latin scutum) - sulustāh hallān soghurū angaryn byolyoh suluha. K. hallān sīgin orduk syrdyk yottyuger bār. Saha siriger kyuhyun, kyhyn, sās kyostyor'. The dictionary starts with the introductory word "From the Author" at the end is the "List of Terms" and references are attached. The introduction "From the 
Author" is about the lack of knowledge of native language, customs, culture and history among modern youth. There is a loss and oblivion of ordinary words denoting objects and things of primordial culture and the environment including astronomical concepts. Examples: Arangas sulus '(Ursa Major)'; Diellyтпу '(Venus)'; Mendenge '(Mercury)'; Oroy Sulus '(Polar Star)'; Sendeli '(Saturn)'; Tayakhtāh Sulus '(Orion)' and others.

Monolingual dictionaries with adapted inclusions. We present the "Linguistic terminology of the Yakut language" as a subaspect of a narrow branch of a monolingual terminological dictionary, compiled by the Candidate of Philogical Sciences, senior lecturer M.A. Cherosov. This dictionary is monolingual - Yakutlanguage, unlike other single branch dictionaries. The title unit of the dictionary, its definition and other additional explanations are all given in Yakut language. This dictionary is for teachers of national schools and students of secondary and higher educational institutions as a teaching guide. Further, it is quite justifiably stated that the terminology of Yakut linguistics refers to the most ordered and functionally used. The first linguists-scientists P.A. Oyunskiy, A.E. Kulakovskiy, G.V. Baishev-Altan Saryn, A.A. Ivanov-Kynde, N.S. Grigoriev and others played a great role at the dawn of the Yakut writing system. The mark kyor 'look' is used consistently in the dictionary. The least used version of the term is referred to the most commonly used with the mark kyor 'look'. The diversity of this method use is particularly evident in relation to the presentation of synonymous terms. The synonymous types are listed alphabetically with the obligatory reference to the generic term. Examples: Biriemē sihilīte kyor sihilī; Buolū sihilīte kyor sihilī; Mieste sihilite kyor sihili etc. As the examples show, the index method for arranging dictionary entries is used in the dictionary. In its final form, The final form of the dictionary entry looks like this: Sihilī 'Haiāhyn buolar miestetin, biriemetin, sorugun, tyoryuotyun uonna tuoh byhȳga-maigyga buolaryn kyordyoryor etī oioghos chiliene .... further, there is a two-paged long encyclopedic explanation of the term sihili with the examples from a literary work. This glossary article ends with an example: Erien Moi kuttalyttan kurūk umsa satȳra (Maxim Sibiryakov)'. As can be seen, the synonymous terms attained their terminological characteristics in the index of the generic term Sihili. Many glossary entries besides their definition and explanations are provided with illustrative examples. Typically, the presence of such a broad illustration is considered unnecessary in terminological dictionaries. In order to achieve unambiguity, Russian equivalents such as Dorghōn tyl (sound language) are sometimes selected to the title units. Dyuhyunnyūr tyl '(figurative words) etc. The dictionary has a brief preface with an explanation of symbols, abbreviations that are found throughout the dictionary.

\section{CONCLUSION}

At times, the Yakut terminology is overly politicized, and has gone a long and difficult way of rise and formation. At present, as shown above, we have dictionaries for all the main subjects of school education, up to the psychological and scientific technical sciences. Single branch postindustrial (inventory and interpretation) dictionaries mark a mature stage in the formation and development of terminological activity. In general, various specific dictionaries laid a solid foundation for the formation of a new terminographic area in Yakut linguistics. This was largely caused by the democratic transformations that swept the whole country in the 90s of the last century. As a result, the Yakut language became the state language along with the Russian language in the Republic of Sakha (1992). Since then, more than twenty years have passed. During this time, radical changes have occurred in the curricula of secondary and vocational schools. In the context of education modernization in the country, an urgent need for updating and re-arranging terminological dictionaries occurs in all subjects of secondary, partially high education, taking into account recent terminographic innovations.

\section{REFERENCES}

[1] I. Kudashev, Terminography vs. lexicography opposition revisited, Översättningsteori, fackspråk och flerspråkighet av VAKKI, 34 (2007) 157.

[2] C.V. Grinev-Grinevich, Introduction to the terminology, Librokom book house, 2009.

[3] M. Łukasik, Contrastive terminography, Cognitive Studies 17 (2017) 14. DOI: https://doi.org/10.11649/cs.1378

[4] E.I. Okoneshnikov, A.S. Akimova, Y.M. Borisova, E.S. Andreev, M.I. Karabaev, To typology of Sakha language terminological lexicon dictionaries, Modern journal of language teaching methods 7(9) 201781.

[5] P.A. Oiyunskiy, Talyllybyt aiymn'ylar, Vol. III, Bichik publishing, 1993.

[6] E.I. Oloneshnikov, Linguistic aspects of Yakut language terminology, Siberian branch of Russian academy of science, Yakut branch, 2006.

[7] Y.M. Borisova, Formation of the basics of Sakha terminological vocabulary (1920-1940s), European Sciences Review Scientific journal 9-10 (SeptemberOctober) (2019) 59-60. 
[8] P.A. Sleptsov, Russian lexical borrowings in Yakut language (post-revolutionary period), Nauka, 1975.

[9] P.A. Sleptsov, Yakut literary language. Formation and development of national standards, Nauka, 1990.

[10] V.I. Byganova, Brief Russian-Yakut dictionary of economics terms, Litograf publishing, 1998.

[11] B.N. Alexeev, V.N. Nikonov, Russian-Yakut law dictionary, Bichik publishing, 2000. 